\title{
Weed species composition and density under conservation agriculture with
}

varying fertilizer rate

Conrad Bakera, b, Ignacio Casper Madakadze ${ }^{\mathrm{b}}$, Corrie Swanepoela ${ }^{\mathrm{a}}$, Zira Mavunganidze $e^{b}$

${ }^{a}$ ARC-Institute for Soil, Climate and Water, P. Bag X79, Pretoria, 0001, South Africa. ${ }^{\text {bDepartment }}$ of Plant Production and Soil Science, University of Pretoria, P. Bag X 20, Hatfield, Pretoria 0028, South Africa. *Conrad Baker, E-mail: conrad66@yahoo.com

\section{ABSTRACT}

Conservation agriculture $(\mathrm{CA})$ is a sustainable management system that optimises yield while reducing input costs. However, reduction in tillage intensity and frequency as practised under CA generally alters weed densities and composition. The objective of the study was to evaluate the effect of tillage, cropping system and fertiliser rate on weed density and diversity under CA systems compared with conventional tillage (CT). An on-station field trial with a split-plot, randomised complete block design, was used and included two tillage systems, three cropping systems and two fertiliser levels. Reduced tillage had significantly $(p<0.05)$ higher weed density $(42 m-2)$ but lower weed biomass (154 g m-2) in contrast to CT with lower weed density (36 m-2) and higher weed biomass (242 $\mathrm{g} \mathrm{m}-2)$. In a principal component analysis ordination, Datura ferox and Tribulus terrestris were more strongly associated with high fertiliser rate, whereas Zinnia peruviana was associated with $\mathrm{CT}$. The increase in weed density and diversity under reduced tillage is likely to restrain the adoption of CA. Therefore, there is a need for alternative weed management options depending upon the weed spectrum, cropping system and fertiliser management.

Keywords: cropping system, fertilizer, tillage systems, weed density. 


\section{Introduction}

Weeds are unwanted plants that interfere with cropping activities. These plants have specific characteristics that make them more competitive under a wide range of environmental and climatic conditions (Labrada and Parker 1994). Furthermore, weeds behave differently in different ecosystems. As such, weeds harbour insects and disease causing pests, which can affect the quality of the crop and increase the likelihood of crop failure. However, different tillage systems provide different types of natural and manipulated habitats to the weeds. Although conventional tillage $(C T)$ is used for weed control before planting, it has long-term consequences that include declining soil organic matter (SOM), increased soil erosion and decreasing biodiversity, and is an unsustainable method of farming (Derpsch 2008; Kassam et al. 2009). Consequently, conservation agriculture (CA) has been promoted as an alternative, feasible and sustainable option as compared with conventional farming systems.

Conservation agriculture aims to reduce external resource input and maximise crop production by increasing soil carbon, which reduces input costs (Hobbs et al. 2008). The basic pillars of CA are minimum soil disturbance, retention of at least $30 \%$ crop residue, and crop rotation (FAO 2012). Nonetheless, high weed infestation in CA is a great challenge for farmers adopting the system (Giller et al. 2009; Mashingaidze et al. 2017). Mulching combined with specific herbicide applications has been used to control weeds (Gill et al. 1992; Mashingaidze et al. 2017). The effectiveness of this approach increases as the mulch thickness builds up.

Various types of implements are utilised in order to till the soil and each has a unique effect on the position and density of weed seeds within the soil profile (Cardina et al. 2002). In reduced tillage (RT) systems, soil is only slightly disturbed during planting 
and most seeds remain in the top $5 \mathrm{~cm}$ of the soil, whereas ploughing typically causes placement of seeds at deeper depths than other tillage systems (Mohler et al. 2006). A chisel plough cuts into the soil, leaving the soil profile relatively intact, and seeds concentrated at the surface, whereas a mouldboard plough turns the soil and redistributes seeds throughout the soil profile (Chauhan et al. 2006).

Changes in soil tillage lead to a shift in weed composition and density (Montanyá et al. 2006; Mashingaidze et al. 2012). Survival and germination of weed seeds in the soil depend on the weed species, depth of burial, soil type and type of tillage (Reuss et al. 2001). On the other hand, buried seeds are more protected from seed-eating animals and are also buffered from extremes of temperature and moisture (Sullivan 2001).

Long-term studies that investigate the direct and interactive effects of CA on weed dynamics are limited (Farooq et al. 2011; Chauhan 2012). A better understanding of weed dynamics in CA systems can help inform management decisions and lead to better implementation of CA. The objective of this study was to investigate the effects of tillage system, mixed cropping patterns and fertiliser management on weed species composition and density after six years of field trials. 


\section{Materials and methods}

\subsection{Study site characteristics}

Data were collected on the Zeekoegat CA trial at the Agricultural Research Council (ARC) experimental farm, north of Pretoria, South Africa $\left(25^{\circ} 36^{\prime} 55^{\prime \prime} \mathrm{S}, 28^{\circ} 18^{\prime} 56^{\prime \prime} \mathrm{E}\right)$.

The Zeekoegat trial was initiated in October 2007 and was terminated after six growing seasons, in May 2013. The soil is moderately fine to medium structured with a clayey texture ( $45 \%$ clay). The long-term annual mean daily minimum and maximum temperatures are $10.8^{\circ} \mathrm{C}$ and $27.1^{\circ} \mathrm{C}$, respectively, and the mean long-term rainfall for the area is $704 \mathrm{~mm} \mathrm{y}-1$ (Figure 1).

\subsection{Experimental design and field procedures}

The experimental layout was a split-plot, randomised complete block design, with three replicates. Each replicate was split into two tillage systems (main plots) with each main plot (RT and CT) further subdivided into six treatments (three cropping systems [sole maize Zea mays $\times$ soybean Glycine max rotation, and maize $\times$ cowpea Vigna unguiculata intercrop] $\times$ two fertiliser levels [subplots]), giving a total of 36 plots.

Fertiliser was applied at two levels: an optimal level and a low level. The optimal level was calculated according to the fertiliser application guidelines and soil analysis, and the low level (50\% of optimal) to mimic reduced input from small-scale farms (Swanepoel et al. 2015). The plot dimensions were $7.2 \mathrm{~m} \times 8 \mathrm{~m}$ with $0.9 \mathrm{~m}$ row spacing for maize and $1.8 \mathrm{~m}$ for tramlines to accommodate intercrops. A mouldboard plough, disk and tine were used to make furrows under $\mathrm{CT}$, whereas tines were used to make furrows under RT. Herbicides used to control weeds during the trial before weed emergence are summarised in Table 1. 


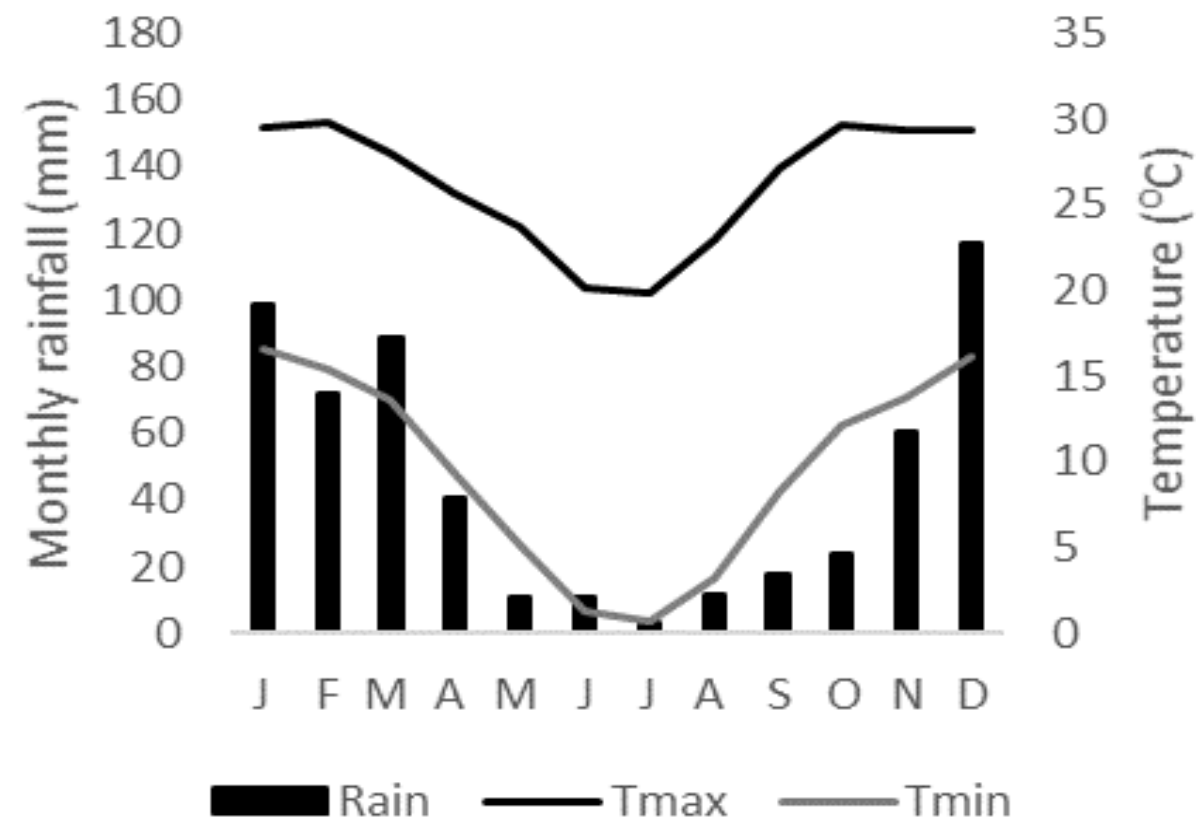

Figure 1. Average monthly rainfall and temperature from 2007 to 2014 seasons. 
Table 1. Weed management at Zeekoegat experimental farm, from 2008 to 2012.

\begin{tabular}{|c|c|c|c|}
\hline \multicolumn{4}{|c|}{ Herbicides applied in both tillage systems RT and CT } \\
\hline $\begin{array}{l}\text { Trade/common } \\
\text { name }\end{array}$ & $\begin{array}{l}\text { Active ingredient } \\
\text { (Al) }\end{array}$ & Application rate & Time of application \\
\hline $\begin{array}{l}1^{\text {st }} \text { application } \\
\text { Springbok }\end{array}$ & Glyphosate $360 \mathrm{~g} \mathrm{l}^{-1}$ & $\begin{array}{l}6 \mathrm{~L} \text { ha-1 ( } \mathrm{L} \text { diluted } \\
\text { into } 200 \mathrm{~L} \mathrm{H}_{2} \mathrm{O} \text { ) }\end{array}$ & $\begin{array}{l}\text { Three times at } \\
\text { planting }\end{array}$ \\
\hline $\begin{array}{l}2^{\text {nd }} \text { application } \\
\text { Round-up/turbo }\end{array}$ & Glyphosate $450 \mathrm{~g} \mathrm{I}^{-1}$ & 3 L ha-1 & $\begin{array}{l}\text { After ploughing ( } 2 \\
\text { weeks before } \\
\text { planting) }\end{array}$ \\
\hline $3^{\text {rd }}$ application & S-Metolachlor & & \\
\hline Round-up/turbo and & (chloro-acetanilide) & - & After planting \\
\hline Dual-Gold 915 C & $915 \mathrm{~g} \mathrm{l}^{-1}$ & & \\
\hline $\begin{array}{l}\text { No herbicides used } \\
\text { bv hand hoes. } \mathrm{Al}=A\end{array}$ & veed control after $\mathrm{C}$ & emergence instead & $\begin{array}{l}\text { ed control was done } \\
\text { ventional Tillage. }\end{array}$ \\
\hline
\end{tabular}




\section{Data collections}

\section{Weed density and biomass}

Weed density and biomass were determined from two randomly placed $1 \mathrm{~m} 2$ quadrats in each plot (Mashingaidze et al. 2012) in February 2014 after six years of practising CA. Weeds were counted and classified by species. Aboveground biomass was determined by oven-drying weeds at $50^{\circ} \mathrm{C}$ to a constant weight.

\section{Statistical analysis}

We assessed the weed species response to tillage and cropping systems by using the relative importance value (RIV) expressed as a percentage. Relative importance value was calculated using the relative frequency and relative density of each species (Chikoye and Ekeleme 2001) in each plot. Percentage relative density was determined as the mean density of each weed species divided by the total weed density for that tillage system multiplied by 100 . Percentage relative frequency was calculated as the frequency of individual weed species within each tillage system divided by the total frequency of all weed species on that tillage system multiplied by 100 . This was done in order to rank each weed species according to importance (Chikoye and Ekeleme 2001). The RIV expressed as a percentage was calculated using the following formula:

$$
R I V=\frac{\text { relative frequency }+ \text { relative density }}{2}
$$

All weed species with an RIV of 10 or less were considered exceptional (Chikoye and Ekeleme 2001).

Shannon-Wiener indices (diversity and evenness) were derived for the various treatments as follows (Pielou 1975): 
$\mathrm{H}^{\wedge}{ }^{\prime}=\frac{\mathrm{N} \operatorname{In} \mathrm{N}-\operatorname{sum}(n \operatorname{In} n)}{\mathrm{N}}$

where $H^{\prime}$ is species diversity through the proportion of the abundance of species, with a higher value signifying greater diversity, $N$ is the sum population density (in $\mathrm{m}^{-2}$ ), and $n$ is the population of each weed species found in the area; and an evenness index $(E)$ :

$\mathrm{E}=\frac{\mathrm{H}^{\wedge}{ }^{\prime}}{\operatorname{In} \mathrm{N}}$

where $E$ is the relationship between the observed number of species and total number of species, with a higher value indicating greater uniformity of species.

Weed count data were square root $(x+0.5)$ transformed prior to analysis to homogenise variances. Analysis of variance (ANOVA) was used to compare the effects of tillage, cropping system, biomass diversity, and Shannon-Wiener indices using procedures in SAS 9.4 (SAS Institute, Cary, NC, USA). The standard error of the difference (SED) was used for mean separation when treatments were significantly different $(p<0.05)$. Principal component analysis (PCA) was used to investigate the treatment and weed species associations. The PCA was conducted using the PCORD multivariate analysis program (McCune and Mefford 2011). The further an arrow is from the centre of the PCA diagram, the greater the confidence that can be placed on the correlation between a species and the variables (tillage, cropping system and fertiliser rate).

\section{Results and discussion}

\section{Effect of tillage on weed density}

Statistical analysis indicated that there was a highly significant difference in weed density, as a result of tillage $(p<0.05)($ Table 2$)$. Reduced tillage had higher weed 
Table 2: Analysis of variance for weed biomass and density at the Zeekoegat experimental farm trial

\begin{tabular}{|c|c|c|c|c|c|c|}
\hline \multirow{2}{*}{ Source of variation } & \multicolumn{3}{|c|}{ Weed biomass } & \multicolumn{3}{|c|}{ Weed density } \\
\hline & DF & Mean sq & P-value & DF & Mean sq & P-value \\
\hline Tillage & 1 & 69895 & $<0.001^{* *}$ & 1 & 289.38 & $0.0154^{*}$ \\
\hline Crop & 2 & 952 & 0.742 & 2 & 71.54 & 0.2047 \\
\hline Fertilizer & 1 & 55 & 0.896 & 1 & 17.47 & 0.5253 \\
\hline Tillage $\times$ Crop & 2 & 545 & 0.843 & 2 & 2.39 & 0.9448 \\
\hline Tillage $x$ Fertilizer & 1 & 2537 & 0.379 & 1 & 29.17 & 0.4131 \\
\hline Crop x Fertilizer & 2 & 2985 & 0.402 & 2 & 205.70 & $0.0173^{*}$ \\
\hline Tillage $\times$ Crop $\times$ Fertilizer & 2 & 6537 & 0.148 & 2 & 87.45 & 0.1481 \\
\hline
\end{tabular}



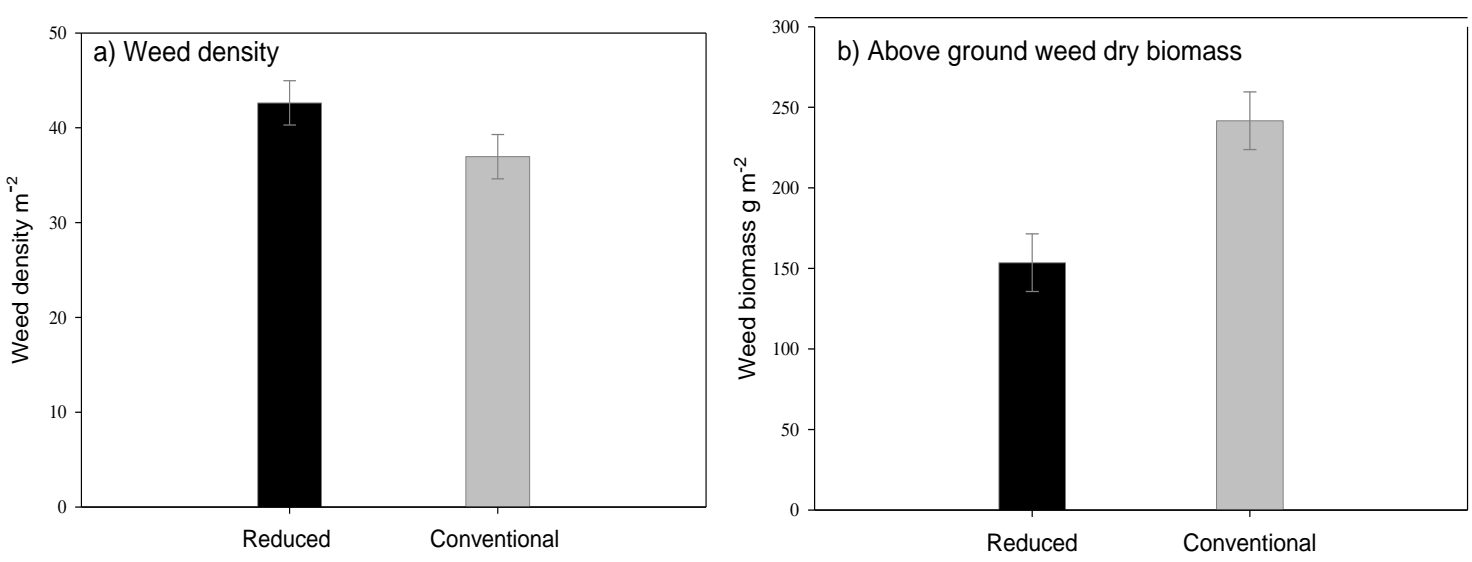

Tillage system

Figure 2. Above-ground a) weed density and b) weed dry biomass under reduced and conventional tillage after termination of Zoekoegat experimental farm trial. Error bars denote SED. 
Table 3. Above-ground weed species observed at Zeekoegat experimental farm conservation agriculture trial, South Africa, listed in order Relative importance value (RIV \%).

\begin{tabular}{|c|c|c|c|c|c|c|c|}
\hline \multirow[b]{3}{*}{ Latin name } & \multirow[b]{3}{*}{ Growth form } & \multicolumn{5}{|c|}{ RIV (\%) tillage system } & \\
\hline & & \multicolumn{3}{|c|}{ Reduced tillage } & \multicolumn{3}{|c|}{ Conventional tillage } \\
\hline & & Sole maize & Rotation & Intercrop & Sole maize & Rotation & Intercrop \\
\hline Schkuhria pinnata L. & ${ }^{\infty} \mathrm{A}$ 3 Dicot & 26.2 & 27.6 & 30.2 & 30.9 & 32.1 & 30.9 \\
\hline Bidens pilosa L. & A Dicot & 19.2 & 15.6 & 22.9 & 16.2 & 14.1 & 16.3 \\
\hline Tagetes minuta L. & A Dicot & 12.8 & 13.5 & 14.4 & 12.1 & 14.7 & 12.1 \\
\hline Axonopous anffinis chase & ap $\psi$ Mono & 7.7 & 9.4 & 9.5 & 6.5 & 7.8 & 6.5 \\
\hline Tribulus terrestris L. & A Dicot & 7.1 & 5.5 & 3.3 & 6.3 & 9.2 & 6.3 \\
\hline $\begin{array}{l}\text { Gomphrena celosioides } \\
\text { (Mart). }\end{array}$ & P Dicot & 3.3 & 4.2 & 3.2 & - & - & - \\
\hline Phalaris minor Retz. & A Mono & 3.2 & 1.4 & - & 1.4 & - & 1.4 \\
\hline Sida rhombifolia L. & P Dicot & 2.7 & 5.2 & - & 1.4 & - & 1.4 \\
\hline Datura ferox $\mathrm{L}$. & A Dicot & 2.7 & 0 & 1.6 & 7.4 & 6.3 & 7.4 \\
\hline $\begin{array}{l}\text { Alternatheara pungens } \\
\text { Kunth. }\end{array}$ & P Dicot & 1.5 & 4.4 & 1.7 & 1.5 & 1.5 & 1.5 \\
\hline Zinnia peruviana L. & A Dicot & - & - & - & 3.1 & 1.5 & 3.09 \\
\hline
\end{tabular}

${ }^{\infty} \mathrm{A}=$ Annual, ${ }^{\alpha} \mathrm{P}=$ Perennials, ${ }^{\psi}$ Mono $=$ Monocotyledon, ${ }^{3}$ Dicot $=$ dicotyledons. 
density $\left(42 \mathrm{~m}^{-2}\right)$ when compared with CT $\left(36 \mathrm{~m}^{-2}\right)$ (Figure $\left.2 \mathrm{a}\right)$. The only significant ( $\mathrm{p}$ $<0.05)$ interaction observed was that of cropping systems $\times$ fertiliser rate on aboveground weed density (Figure 3). Annual weeds (seven species) were the most dominant group under both tillage systems compared with the perennials (four species) (Table 3).

The high weed density under RT as compared with CT treatments could be due to the absence of tillage, which incorporates weed seeds in the top-soil layers. As a result weed seeds accumulate in top-soil layers (Weber et al. 2017), where conditions are favourable for germination (Benvenuti et al. 2001). In non-moisture-limiting conditions germination stimulus is generally higher near the soil surface (which is light-rich with diurnal temperature fluctuations) and decreases with depth (dark with buffered temperature changes). Given that RT seedbanks are concentrated in the top layer of the soil, a higher proportion of RT seedbanks will germinate compared with that of CT seedbanks. Mashingaidze et al. (2012) reported that weed density will increase in the first years but decline and become easier to control with time under RT. However, in the present study even after six years of practising RT higher weed densities were still persistent as compared with $\mathrm{CT}$, emphasising that other management factors are important. There are several reasons that explain the different findings, which include differences in mulching rates, weed management, cropping system and environment (Mhlanga et al. 2015). Nonetheless, assuming there is no seedbank replacement over time under RT, weed seedbanks are likely to be depleted and reduce the germinable weeds. The transition period will depend on management factors.

\section{Cropping system and fertilizer interaction on weed density}

There was a significant $(p<0.05)$ interaction between cropping system and fertiliser application rate (Table 2). Figure 3 shows that sole maize $\times$ low fertiliser resulted in 


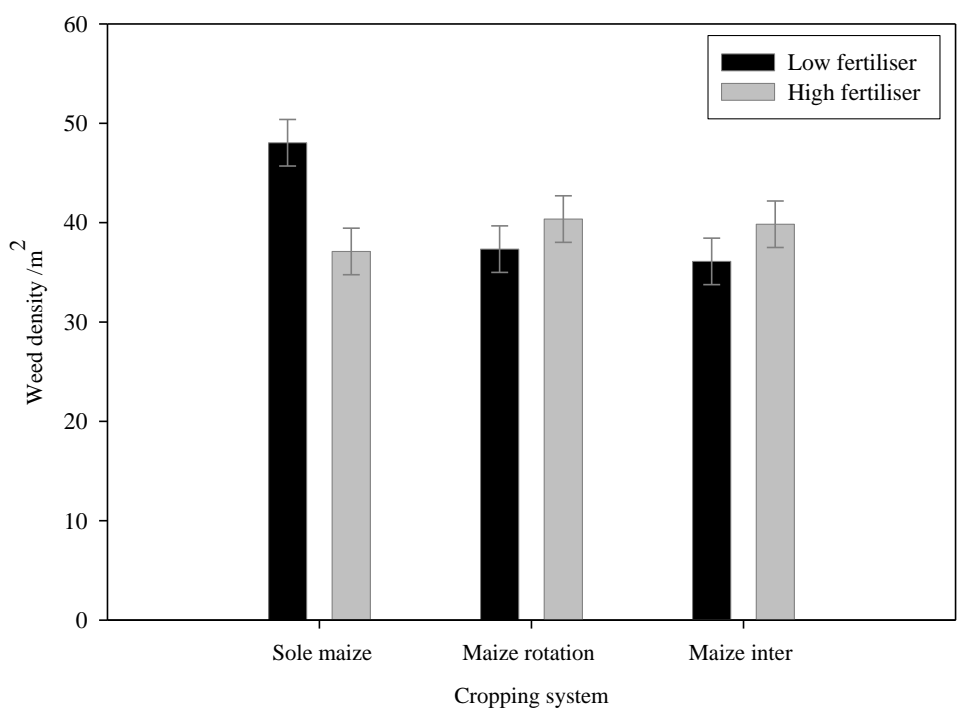

Figure 3. Effect of cropping system and fertilizer interaction on above-ground weed density after termination of Zeokoegat experimental farm trial. Error bars denote SED. 
higher weed density, but all other treatments were not significantly different to each other.

In terms of crop management practices, each crop would result in different ecological conditions for weeds with regard to light conditions or growth penology (Hallgren et al. 1999). Similar results were observed for maize $\times$ cowpeas intercropping, which led to higher soil, canopy cover and decreased light availability for weeds, resulting in a reduction in weed density and dry matter compared with sole crops (Kumar et al. 2010).

Significantly higher weed density was observed in sole maize in comparison with maize $\times$ rotation and maize $\times$ intercrop. Likewise, the minor role played by crop rotation in the control of weed density in comparison with tillage treatments is in line with results reported by Doucet et al. (1999). In fact, crop rotation is an effective practice for controlling serious weeds because it affects weed growth and reproduction negatively and as a result reduces weed density (Derksen et al. 1993; Blackshaw et al. 1994). The reduction in weed competitiveness due to crop rotation observed in this experiment is in agreement with other investigations in which cropping sequence reduced weed density (Blackshaw et al. 1994).

Nutrient availability influences weed crop competition (Evans et al. 2003), but the response varies with type of weed species, crop and nutrient status of the soil. Weaver et al. (1992) reported nutrient availability as one dynamic approach that can influence duration and extent of competition. However, while nutrients clearly promote crop growth, many studies have shown that fertilisers benefit weeds more than crops, and increased weed density and biomass was observed following fertiliser application (Légère et al. 1994; Santos et al. 1998). 
Certain weed species have a lower optimal rate of nitrogen $(\mathrm{N})$ fertiliser than crops, giving weeds a competitive advantage in some situations (Tabachnick and Fidell 1996). Everaarts (1992) reported that $\mathrm{N}$ and phosphorus (P), but not potassium (K), application stimulated weed growth on a sandy loam soil. Similarly, Ugen et al. (2002) observed greater weed growth in a non-weeded bean (Phaseolus vulgaris) crop with $\mathrm{N}$ and $\mathrm{P}$ application. Fertiliser can also favour certain weeds and therefore has the potential to shift weed species (Liebman and Mohler 2001).

Tillage, cropping systems and fertilizer effect on individual weed species

A total of 11 weed species (seven annual species and four perennials) were identified in the study area. Schkuhria pinnata, Bidens pilosa and Tagetes minuta had the highest RIV (Table 3). These three weed species, which had the highest RIV percentages, are considered therophytes. The perennial dicot Gomphrena celosioides was absent under CT in all cropping systems, whereas the annual dicot Zinnia peruviana was only absent under RT in all cropping systems. Phalaris minor and Sida rhombifolia were not observed in crop rotation under CT. The RIV differed with tillage and cropping system (Table 3). The RIV for Schkuhria pinnata was higher under CT than under RT and crop rotation with CT had highest RIV (32.07\%). Weed species with lower RIV (\%) in the cropping system were mostly perennials. The highly significant influence of tillage management played a vital role in regulating the relative abundance of weed species diversity (Table 3).

Certainly, high-disturbance environments such as CT systems have been reported to favour annual broadleaves, whereas lower-disturbance RT systems favour perennial weeds and species that can easily germinate in the top soil layer such as annual grasses (Menalled et al. 2001; Taa et al. 2004). The results are in agreement with Moyer et al. (1994), who observed that there are certain annual or perennial weeds 
that thrive in RT systems and others that are suppressed (Table 3 ). This may be because RT systems still experience periodic disturbance via field activities and, depending on the timing, activities that damage or remove aboveground material (e.g. harvest) can successfully destroy perennials (Mohler 2001). Swanton et al. (1993) observed no consistent trend in long-term tillage studies regarding increases in perennial weeds, and concluded that changes in weed management often associated with crop rotation play an important role to play in dictating weed communities. Reduced tillage may increase the selection of weed species whose lifecycles and resource demands complement those of the agronomic crop, regardless of classification (Dorado et al. 1999). Indeed, there are reports where changing to RT in rotations including two or more crops did not result in an increase in perennial weeds (Derksen et al. 1993; Blackshaw et al. 2001).

\section{Weed biomass}

There was a significant $(p<0.05)$ effect of tillage system on weed biomass (Table 2$)$. Aboveground weed biomass was higher under CT than RT with averages of $241.66 \mathrm{~g}$ $\mathrm{m}^{-2}$ and $153.53 \mathrm{~g} \mathrm{~m}^{-2}$, respectively (Figure $2 \mathrm{~b}$ ). Conventional tillage had the highest weed biomass, whereas RT had the lowest biomass (Figure 2b). The evaluated main effects, i.e. cropping system and fertiliser rate, did not significantly $(p>0.05)$ affect weed biomass.

Improved weed growth conditions under CT may have resulted in higher weed biomass than RT (Figure 2). Tillage reduces resistance to root and seedling penetration, which affects growth and establishment of germinated weed seeds (Verhulst et al. 2010). However, this finding is in contrast with Velykis and Satkus (2006) who reported that RT resulted in higher weed biomass and density compared with CT. The differences in soil types, cropping systems and environments have 
contributed to the observed different results. Abdin et al. (2000) reported higher weed biomass in the rows than between the rows probably due to inter-row cultivation. Swanton et al. (1999) and Shrestha et al. (2002) demonstrated that the processes that determine weed shifts, composition, density and weed biomass are very complex. However, previous studies have shown that plant height uniformity with increased plant density can significantly reduce weed biomass and increase yields in a variety of crops (Olsen et al. 2012; Marín and Weiner 2014).

\section{Diversity indexes}

The interaction effect of cropping system $\times$ low fertiliser rate on weed species diversity was significant, but no significant effect was observed on other treatments (Table 4). Shannon's diversity index, a measure for comparison of species diversity, usually ranges from zero to five (Booth et al. 2003). The highest Shannon index value for weed species diversity was in sole maize under low fertiliser (1.55) compared with that for maize $\times$ cowpea intercrop under low fertiliser (1.38) (Table 4). Weed control in situations of increased crop density is usually achieved through pronounced shading of weeds (Mhlanga et al. 2016), resulting in earlier canopy closure, thus shading weeds in their early developmental stages (Vera et al. 2006). Hence weed diversity was highest under sole maize $\times$ low fertiliser (Table 4). At relatively low crop densities, crop cover early in the growing season is low, leaving a larger amount of resources available for weeds, thus enabling them to establish and grow quickly (Kristensen et al. 2008). Moreover, weeds grow slower at low fertilisation levels (Blackshaw et al. 2003).

In addition, weed density, cropping system and fertilizer had the greatest effect on weed species diversity (Table 4). This trend support Nolan and Callahan (2006) and Mhlanga et al. (2015), who reported that rotations with cover crops ultimately lead to 
Table 4: The effect of cropping system and fertilizer on Shannon index diversity interaction and Shannon index evenness interaction for weed species at Zeekoegat experimental farm.

\begin{tabular}{|c|c|c|c|c|c|c|}
\hline \multirow[t]{2}{*}{$\begin{array}{l}\text { Cropping } \\
\text { system }\end{array}$} & \multicolumn{3}{|c|}{$\begin{array}{c}\text { Shannon index diversity } \\
\text { interaction }\end{array}$} & \multicolumn{3}{|c|}{$\begin{array}{c}\text { Shannon index evenness } \\
\text { interaction }\end{array}$} \\
\hline & $\begin{array}{l}\text { Low } \\
\text { fertilizer }\end{array}$ & $\begin{array}{l}\text { High } \\
\text { fertilizer }\end{array}$ & P-value & $\begin{array}{l}\text { Low } \\
\text { fertilizer }\end{array}$ & $\begin{array}{l}\text { High } \\
\text { Fertilizer }\end{array}$ & P-value \\
\hline $\begin{array}{l}\text { Sole maize } \\
\text { Maize x }\end{array}$ & $1.55 \mathrm{a}$ & $1.40 \mathrm{~b}$ & & $0.402 \mathrm{ab}$ & $0.388 a b$ & \\
\hline $\begin{array}{l}\text { cowpea/soybean } \\
\text { rotation }\end{array}$ & $1.40 \mathrm{~b}$ & $1.44 \mathrm{ab}$ & 0.013 & $0.386 \mathrm{~b}$ & $0.391 a b$ & 0.037 \\
\hline Maize x cowpea & $1.38 \mathrm{~b}$ & $1.48 a b$ & & $0.387 \mathrm{~b}$ & $0.404 \mathrm{a}$ & \\
\hline & $\mathrm{CV} \%=$ & 5.0 & & $\mathrm{CV} \%=1$ & & \\
\hline
\end{tabular}

Significant difference are denoted by different letters $a$ and $b(P<0.05)$, means that share a letter are not significantly different. 
reduced weed numbers of dominant weeds to low levels hence increasing weed species diversity, but these responses depend on other factors such as quality of season and other agronomic management practises. This suggests that crop rotations may promote or increase weed species diversity (Palmer and Maurer 1997; Murphy et al. 2006), moreover, the source of nutrient enrichment in a rotation may also influence the composition of the weed community (Wortman et al. 2010). The results complement Murphy and Lemerle, (2006) findings that fertilization affects not only the growth of crop but also on weed population. However, previous studies have shown that fertilization can significantly affect weed community composition, density and diversity (Moss et al. 2004; Wan et al. 2012).

\section{Cropping system and fertilizer rate on weed species evenness}

There was a significant $(p<0.05)$ interaction between cropping system $\times$ fertiliser on weed species evenness (Table 4). Maize $\times$ cowpea intercrop had a high evenness index under high fertiliser and declined as fertiliser level decreased (Table 4). Maize $\times$ cowpea/soybean rotation had a low evenness under low fertiliser and gradually increased as the fertiliser level increased (Table 4).

The observed higher evenness indices under maize $\times$ cowpea intercrop with high fertiliser is in line with Mhlanga et al. (2015), as indicated that when more weed species emerge, or when dominant weed species decline in number, the chances of dominance of a few weed species is reduced thus raising the weed species evenness. The predominance of certain weeds in the field under sole maize with low fertiliser and maize $\times$ intercrop with high fertiliser might be likely due to these cropping systems exposing seeds to germination stimuli such as light (Scopel et al. 1994). Crop and fertiliser interaction had an effect on species evenness (Table 4). When densely sown and appropriately fertilised, crops can effectively suppress weed growth and reduce 
evenness of understory weeds (Poggio 2005). Manipulating crop canopies can, thus, serve to maximise the sunlight that is intercepted, resulting in increased shading effects on weeds (Holt 1995).

The principal component analysis (PCA) ordination on tillage and cropping systems.

The only significant $(p<0.002)$ relationship obtained from the PCA was on the first axis. The first and second axes represented $54.47 \%$ and $23.38 \%$ of the total variation, respectively (Figure 4). The PCA ordination clearly separated aboveground weed species associated with tillage, cropping system and fertiliser (Figure 4). Axonopus affinis, S. pinnata and Alternanthera pungens were more associated with maize $\times$ cowpea/soybean rotation and low fertiliser under the RT system. Gomphrena celosioides, Sida rhombifolia, T. minuta and P. minor were more closely associated with sole maize under reduced tillage. These findings support those of Smith et al. (1992) and Holm et al. (1997) that S. rhombifolia has become an increasingly problematic weed with the advent of reduced or no-tillage cropping systems. The pattern of seed distribution within a field generally follows the direction of crop rows and the greatest diversity of weed species found at the edges (Cavers and Benoit 1989). The vertical distribution of seeds depends on the treatment given to the soil: under RT, the seeds are concentrated in the upper horizons, whereas under CT the seeds are mostly found at intermediate depths (Benvenuti 2007). Datura ferox and Tribulus terrestris were more closely associated with high fertiliser and $Z$. peruviana under CT.

Crop rotations are debatably the most effective means to control weeds. Every crop has a characteristic set of biotic and abiotic suppression activities on the weed community; this promotes the growth of some weeds while inhibiting that of others. Furthermore, any given crop can act as a filter, by allowing certain weeds to adapt to 


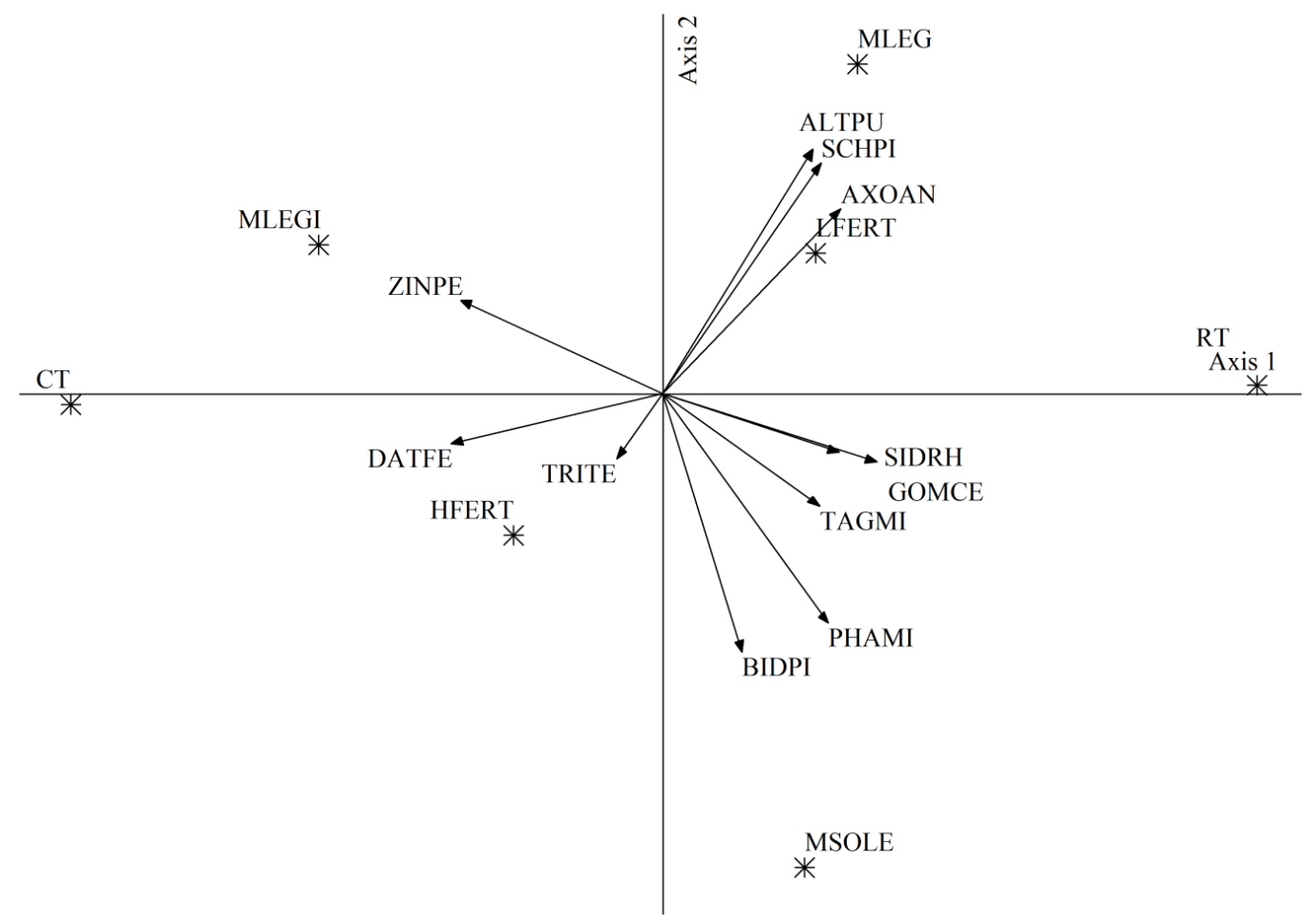

Figure 4. Principal component analysis (PCA) ordination diagram of above - ground weed species in tillage, cropping system and fertilizer rate. Measured variables are indicated by vectors from first axis and second axis. Conventional tillage: CT; Reduced tillage: RT; Maize sole: MSOLE; Maize legume rotation: MLEG; Maize legume intercrop: MLEGl; High fertilizer: HFERT; Low fertilizer: LFERT; S. rhombifolia L: SIDRH, A. anffinis chase: AXOAN, B. pilosa: BIDPI, T. terrestris L: TRITE, S. pinnata: SCHPI, A. pungens: ALTPU, T. minuta L: TAGMI, D. ferox L:DATFE, P. minor: PHAMI, G. celosioides (Mart): GOMCE, Z. peruviana L: ZINPE. 
its management regime (Booth and Swanton 2002). Weed density increases when they mimic the crop lifecycle (Derksen et al. 2002). Countless studies also reported an increase in weed diversity under these conditions (Dorado et al. 1999; Sosnoskie et al. 2006).

Monocultures often result in fewer dominant weed species (Blackshaw et al. 2001; Cardina et al. 2002). This makes herbicide selection easy but it possibly increases selection pressure for herbicide-resistant weeds. Most studies indicated that crop rotation reduces weed densities compared with monocultures irrespective of tillage regime. However, for a given crop rotation, whether RT results in higher weed density relative to tilled systems is not clear and probably is dependent upon other factors. Some studies show that RT works synergistically with rotations to help reduce weed densities compared with tilled systems (Anderson 2005; Murphy et al. 2006). In addition, the PCA ordination results confirm that the impact of tillage system on species diversity remains inconclusive with cases where RT had proved to increase diversity (Mas and Verdu 2003; Sosnoskie et al. 2006). 


\section{Conclusion}

The RT system resulted in higher weed density and low weed biomass compared with those of the CT system after a six-year study of CT and RT systems. The PCA showed that the RT system was associated with both annual and perennial dicot weeds, whereas the CT system comprised mostly of annual dicot weeds. However, the effect of tillage on weed density, biomass and diversity was dependent upon the cropping system and fertiliser level used. Sole maize under a low fertiliser level resulted in a higher diversity index than sole maize under a high fertiliser level. It is therefore important to reduce the weed seeds that enter into the weed seedbank under the RT system with the aim of reducing weeds that emerge from the soil under RT. It is important for scientists to develop new weed management options under RT that will effectively control weeds depending upon the cropping system, fertiliser management and the dominant weed species in any particular field.

\section{Acknowledgements}

The authors would like to acknowledge ARC- Institute for Climate, Soil and Water; Maize Trust and University of Pretoria for funding. Special thanks to Dr Thomas Fyfield for proofreading this manuscripts. 


\section{REFERENCES}

Abdin OA, Zhou XM, Cloutier D, Coulman BC, Faris MA, Smith DL. 2000. Cover crops and inter-row tillage for weed control in short season maize (Zea mays). European Journal of Agronomy 12: 93-102.

Anderson RL. 2005. A multi-tactic approach to manage weed population dynamics in crop rotations. Agronomy Journal 97: 1579-1583.

Benvenuti S, Macchia M, Miele S. 2001. Quantitative analysis of emergence of seedlings from buried weed seeds with increasing soil depth. Weed Science 49: $528-535$.

Benvenuti S. 2007. Natural weed seed burial: effect of soil texture, rain and seed characteristics. Seed Science Research 17: 211-219.

Blackshaw R, Larney F, Lindwall C, Watson P, Derksen D. 2001. Tillage intensity and crop rotation affect weed community dynamics in a winter wheat cropping system. Canadian Journal of Plant Science 81: 805-813.

Blackshaw RE, Brandt RN, Janzen HH, Entz T, Grant CA, Derksen DA. 2003. Differential response of weed species to added nitrogen. Weed Science 51:532539.

Blackshaw RE, Larney FO, Lindwall CW, Kozub GC. 1994. Crop rotation and tillage effects on weed populations on the semi-arid Canadian prairies. Weed Technology 8: 231-237.

Booth BD, Murphy SD, Swanton CJ. 2003. Weed ecology in natural and agricultural systems, Cambridge: CABI Publication. 
Booth BD, Swanton CJ. 2002. Assembly theory applied to weed communities. Weed Science 50: 2-13.

Cardina J, Herms CP, Doohan DJ. 2002. Crop rotation and tillage system effects on weed seedbanks. Weed Science 50: 448-460.

Cavers PB, Benoit DL. 1989. Seed banks in arable land. In: Leck MA; Parker VT, Simpson RL. (Eds), Ecology of soil seed banks. New York, Academic Press. pp. 309-328.

Chauhan B, Gill G, Preston C. 2006. Influence of tillage system on vertical distribution, seedling recruitment and persistence of rigid ryegrass (Lolium rigidorum) seed bank. Weed Science 54: 669-676.

Chauhan BS. 2012. Weed ecology and weed management strategies for dry seeded rice in Asia. Weed Technology 26: 1-13.

Chikoye D, Ekeleme F. 2001. Weed flora and soil seedbanks in fields dominated by Imperata cylindrica in the moist savanna of West Africa. Weed Research 41: 475-490.

Derksen DA, Anderson RL, Blackshaw RE, Maxwell B. 2002. Weed dynamics and management strategies for cropping systems in the Northern Great Plains. Journal of Agronomy 94: 174-185.

Derksen DA, Lafond GP, Thomas AG, Loeppky HA, Swanton CJ. 1993. Impact of agronomic practices on weed communities: tillage systems. Weed Science 41: 409-417.

Derpsch R. 2008. No-tillage and conservation agriculture. A progress report. In: Goddard T, Zoebisch MA, Gen YT, El-Lis W, Watson A, Soubatpenit S (Eds), 
No-till farming systems. Special publication No. 3, World Association of Soil and Water Conservation, Bangkok. 60: 1-544.

Dorado J, Del Monte J, Lopez-Fando C. 1999. Weed seedbank response to crop rotation and tillage in semiarid agroecosystems. Weed Science 47: 67-73.

Doucet C, Weaver S, Hamill AS, Zhang J. 1999. Separating the effects of crop rotation from weed management on weed density and diversity. Weed Science 47: 729735.

Evans SP, Knezevic SZ, Shapiro C, Lindquist JL. 2003. Nitrogen level affects critical period for weed control in corn. Weed Science 51: 408-417.

Everaarts AP. 1992. Response of weed to application of nitrogen, phosphorus and potassium on low- fertility acid soils in Suriname. Weed Research 32: 385-390.

FAO (Food and Agriculture Organization of the United Nations). 2012. Conservation agriculture and sustainable crop intensification: a Zimbabwe case study. Integrated Crop Management vol. 17. Rome: FAO.

Farooq M, Flower K, Jabran K, Wahid A, Siddique KH. 2011. Crop yield and weed management in rain-fed conservation agriculture. Soil and Tillage Research 117 $172-183$.

Gill KS, Arshad MA, Chivundu BK, Phiri B and Gumbo M. 1992. Influence of residue mulch, tillage and cultural practices on weed mass and corn yield from three field experiments. Soil and Tillage Research 24: 211-223.

Giller KE, Witter E, Corbeels M, Tittonell P. 2009. Conservation agriculture and smallholder farming in Africa: The heretic's view. Field Crops Research 114: 2334. 
Hallgren E, Palmer MW, Milberg P. 1999. Data diving with cross-validation: an investigation of broad-scale gradients in Swedish weed communities. Ecology Journal 87: 1037-1051.

Hobbs PR, Sayre K, Gupta R. 2008. The role of conservation agriculture in sustainable agriculture. Philosophical Transactions of the Royal Society B 363: 543-555.

Holm L, Doll J, Holm E, Pancho J, Herberger J. 1997. World weeds. New York, John Wiley and Sons.

Holt JS. 1995. Plant responses to light: a potential tool for weed management. Weed Science 43: 474-482.

Kassam A, Friedrich T, Shaxson F, Pretty J. 2009. The spread of conservation agriculture: justification, sustainability and uptake. International Journal of Agricultural Sustainability 7: 292-320.

Kristensen L, Olsen J, Weiner J. 2008. Crop density, sowing pattern, and nitro- gen fertilization effects on weed suppression and yield in spring wheat. Weed Science 56:97-102.

Kumar RD, Sreenivasulu GB, Prashanth SJ, Jayaprakashnaraya-Yan RP, Nataraj SK, Hegde NK. 2010. Performance of ginger in tamarind plantation (as intercrop) compared to sole cropping (ginger). International Journal of Agricultural Sciences 6: 193-195.

Labrada R, Parker C. 1994. Weed control in the context of integrated pest management, weed management for developing countries. In: Labrada R, Caseley JC, Parker C (Eds), Plant Production and Protection Paper No. 120, FAO, Rome. pp. 3-8. 
Légère A, Simard RR, Lapierre C. 1994. Response of spring barley and weed communities to lime, phosphorus and tillage. Canadian Journal of Plant Science 74: $421-428$.

Liebman M, Mohler CL. 2001. Weeds and the soil environment. In: Liebman M, Mohler CL, Staver CP (eds), Ecological management of agricultural weeds. Cambridge: Cambridge University Press. pp 210-269.

Marín C, Weiner J. 2014. Effects of density and sowing pattern on weed suppression and grain yield in three varieties of maize under high weed pressure. Weed Research 54: 467-474.

Mas MT, Verdu AMC. 2003. Tillage system effects on weed communities in a 4-year crop rotation under Mediterranean dryland conditions. Soil and Tillage Research 74: 15-24.

Mashingaidze N, Madakadze C, Twomlow S, Nyamangara J, Hove L. 2012. Crop yield and weed growth under conservation agriculture in semi-arid Zimbabwe. Soil and Tillage Research 124: 102-110.

Mashingaidze N, Twomlow S, Madakadze IC, Mupangwa W, Mavunganidze Z. 2017. Weed growth and crop yield responses to tillage and mulching under different crop rotation sequences in semi-arid conditions. Soil Use and Management 33: 311-327.

McCune B, Mefford MJ. 2011. PC-ORD. Multivariate analysis of Ecological Data, Version 6.0 for Windows. 
Menalled FD, Gross KL, Hammond M. 2001. Weed aboveground and seedbank community responses to agricultural management systems. Journal of Applied Ecology 11: 1586-1601.

Mhlanga B, Chauhan BS, Thierfelder C. 2016. Weed management in maize using crop competition: a review. Crop Protection 88: 28-36.

Mhlanga B, Cheesman S, Maasdorp B, Muoni T, Mabasa S, Mangosho E, Thierfelder C. 2015. Weed community responses to rotations with cover crops in maizebased conservation agriculture systems of Zimbabwe. Crop Protection 69: 1-8.

Mohler C. 2001. Ecological management of agricultural weeds: 139-209.

Mohler CL, Frisch JC, Mcculloch CE. 2006. Vertical movement of weed seed surrogates by tillage implements and natural processes. Soil and Tillage Research 86: 110-122.

Montanya IS, Catalan G, Tenorio JL, Garcia-Baudin JM. 2006. Effect of the tillage systems on weed flora composition. Options Méditerranéennes CIHEAM 69: $143-147$.

Moss SR, Storkey J, Cussans JW, Perryman SAM, Hewitt MV. 2004. The Broadbalk long-term experiment at Rothamsted: What has it told us about weeds? Weed Science 52: 864-873.

Moyer J, Roman E, Lindwall C, Blackshaw R. 1994. Weed management in conservation tillage systems for wheat production in North and South America. Crop Protection 13: 243-259.

Murphy CE, Lemerle D. 2006. Continuous Cropping Systems and Weed Selection. Euphyta 148: 61-73. 
Murphy SD, Clements DR, Belaoussoff S, Kevan PG, Swanton CJ. 2006. Promotion of weed species diversity and reduction of weed seedbanks with conservation tillage and crop rotation. Weed Science 54: 69-77.

Nolan KA and Callahan JE. 2006. Beachcomber biology: the Shannon-Weiner species diversity index. In: Proc. Workshop ABLE. pp. 334-338.

Olsen JM, Griepentrog HW, Nielsen J, Weiner J. 2012. How important are crop spatial pattern and density for weed suppression by spring wheat? Weed Science 60: 501-509.

Palmer MW and Maurer TA. 1997. Does diversity beget diversity? A case study of crops and weeds. Journal of Vegetation Science 8: 235-240.

Pielou EC. 1975. Ecological Diversity. Wiley, London.

Poggio SL. 2005. Structure of the weed communities occurring in monocultures and intercrops of field pea and barley. Agriculture, Ecosystems and Environment 109: $48-58$.

Reuss SA, Buhler DD, Gunsolus JL. 2001. Effects of soil depth and aggregate size on weed seed distribution and viability in a silt loam soil. Applied Soil Ecology 16: 209-217.

Santos B, Dusky JA, Stall WM, Shilling DG, Bewick TA. 1998. Phosphorous effects on competitive interactions of smooth pigweed (Amaranthous hybridus) and common purslane (Portulaca oleracea) with lettuce. Weed Science 46: 307-312.

Scopel AL, Ballare CL, Radosevich SR. 1994. Photo stimulation of seed germination during soil tillage. New Phytologist 126: 145-152. 
Shrestha A, Knežević SZ, Roy RC, Ball-Coelho BR, Swanton CJ. 2002. Effect of tillage, cover crop and crop rotation on the composition of weed flora in a sandy soil. Weed Research 42: 76-87.

Smith CA, Shaw DR, Newsom LJ. 1992. Arrowleaf sida (Sida rhombifolia) and prickly sida (Sida spinosa): germination and emergence. Weed Research 32: 103-109.

Sosnoskie LM, Herms NP, Cardina J. 2006. Weed seed bank community composition in a 35-yr-old tillage and rotation experiment. Weed Science 54: 263-273.

Sullivan P. 2001. Principles of sustainable weed management for croplands. ATTRA University of Arkansas, Fayetteville. (www.attra.ncat.org).

Swanepoel CM, Habig J, Thiebaut N, Swanepoel LH. 2015. Temporal variation in weed occurrence and biomass under conservation agriculture and conventional farming practices. African Journal of Agricultural Research 20: 3921-3929.

Swanton CJ, Clements DR, Derksen DA. 1993. Weed succession under conservation tillage: a hierarchical framework for research and management. Weed Technology 7: 286-297.

Swanton CJ, Shrestha A, Knežević SZ, Roy RC, Ball-Coelho BR. 1999. Effect of tillage systems, N, and cover crop on the composition of weed flora. Weed Science 47: 454-461.

Taa A, Tanner D, Bennie AT. 2004. Effects of stubble management, tillage and cropping sequence on wheat production in the South-Eastern highlands of Ethiopia. Soil and Tillage Research 76: 69-82.

Tabachnik BG, Fidell LS. 1996. Using multivariate statistics. ( $3^{\text {rd }}$ ed), New York: Harper Collins College. 
Ugen MA, Wien HC, Wortmann CS. 2002. Dry bean competitiveness with annual weeds as affected by soil nutrient availability. Weed Science 50: 530-535.

Velykis A, Satkus A. 2006.Influence of crop rotations and reduced tillage on weed population dynamics under Lithuania's heavy soil conditions. Agronomy Research 4: 441-445.

Vera CL, Woods SM, Raney JP. 2006. Seeding rate and row spacing effect on weed competition, yield and quality of hemp in the Parkland region of Saskatche-wan. Can. Plant Science Journal 86: 911-915.

Verhulst N, Govaerts B, Verachtert E, Castellanos-Navarrete A, Mezzalama M, Wall, P, Chocobar A, Deckers J, Sayre K. 2010. Conservation agriculture, improving soil quality for sustainable production systems. In: Lal R, Stewart BA (Eds), Advances in Soil Science: Food Security and Soil Quality. pp 137-208.

Wan KY, Yong T, Ruhai L, Jun FP, Lei LT, Fang C. 2012. Influences of long-term different types of fertilization on weed community biodiversity in rice paddy fields. Weed Biology and Management 12: 12-21.

Weaver SE, Kropff MJ, Groeneveld RMW. 1992. Use of eco-physiological models for crop weed interference: the critical period of weed interference. Weed Science 40: 302-307.

Weber J, Kunz C, Peteinatos G, Zikeli S, Gerhards R. 2017. Weed control using conventional tillage, reduced tillage, no-tillage, and cover crops in organic soybean. Agriculture 7: 43. 
Wortman SE, Lindquist JL, Haar M, Francis CA. 2010. Increased weed diversity, density and aboveground biomass in long-term organic crop rotations. Renewable Agriculture and Food Systems Journal 25: 281-295. 